\begin{tabular}{|c|c|c|}
\hline & JSM (9) (1) & 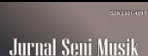 \\
\hline y & JURNAL SENI MUSIK & \\
\hline & https://journal.unnes.ac.id/sju/index.php/jsm/index & \\
\hline
\end{tabular}

\title{
PRESENTATION AND FUNCTION OF THE JAVANESE SONG FOR THE CHOIR IN EUCHARIST CEREMONY AT ST. MARIA FATIMA BANYUMANIK SEMARANG \\ Ignatius Christo Charity ${ }^{\otimes 1}$ \\ Totok Sumaryanto Florentinus $^{\otimes 2}$ \\ Eko Raharjo \\ Department of Drama, Dance, and Music, Faculty of Languange and Arts, UNNES.
}

\begin{tabular}{l} 
Article Info \\
\hline Received March 2020 \\
Approved April 2020 \\
Published June 2020
\end{tabular}

Keywords:

Javanese language song,

choir, eucharistic celebration

\begin{abstract}
Abstrak
Perayaan ekaristi yang menggunakan bahasa jawa sangatlah jarang dilaksanakan di gereja katolik, oleh sebab itu menimbulkan kurangnya pengetahuan masyarakat terutama umat mengenai perayaan ekaristi bahasa Jawa. Penelitian ini dilakukan bertujuan untuk memberikan informasi dan pengetahuan kepada masyarakat mengenai bentuk penyajian dan fungsi dari lagu bahasa Jawa untuk paduan suara yang digunakan untuk mengiringi perayaan ekaristi bahasa Jawa yang dilaksanakan di gereja katolik St. Maria Fatima Banyumanik Semarang. Penelitian yang bersifat deskriptif - kualitatif ini berlangsung di Gereja St. Maria Fatima Banyumanik Semarang pada tanggal 26 Mei dan 30 Juni 2019 dengan romo, petugas paduan suara dan umat gereja sebagai subjek penelitian. Teknik pengumpulan data dalam penelitian ini meliputi observasi, wawancara dan studi dokumen. Teknik analisis data yang digunakan adalah analisis interaktif. Hasil dari penelitian mengungkapkan bahwa bentuk penyajian lagu liturgi bahasa Jawa yang digunakan untuk mengiringi perayaan ekaristi bahasa Jawa di Gereja St. Maria Fatima Banyumanik Semarang sama dengan bentuk penyajian lagu liturgi perayaan ekaristi pada umumnya yaitu berbentuk kelompok paduan suara, dan fungsi penggunaan lagu liturgi bahasa Jawa dalam perayaan ekaristi adalah sebagai sarana komunikasi serta sebagai kontribusi berkelanjutan dan stabilitas budaya. Semoga kedepannya pihak gereja lebih gencar menginformasikan perayaan ekaristi bahasa Jawa kepada umatnya, dan semoga paduan suara yang bertugas dapat menyiapkan teks lagu untuk umat, sehingga dapat meningkatkan kesiapan dan juga antusias umat dalam mengikuti perayaan ekaristi bahasa Jawa di Gereja St. Maria Fatima
\end{abstract} Banyumanik Semarang.

\begin{abstract}
Eucharistic celebrations that use Javanese language are very rarely carried out in the Catholic church, thereby causing a lack of public knowledge, especially people about Javanese Eucharist. This research was conducted aiming to provide information and knowledge to the public about the form and presentation of the Javanese song for the choir used to accompany the celebration of the Javanese eucharist held at the church St. Maria Fatima Banyumanik Semarang. This descriptive - qualitative research took place at St. Maria Fatima Banyumanik Semarang on May 26 and June 30, 2019 with a priest, choir officer and church members as research subjects. Data collection techniques in this study include observation, interviews and document studies. The data analysis technique used is interactive analysis. The results of the study revealed that the form of Javanese liturgical song presentation was used to accompany the celebration of the Javanese eucharist at the Church of St. Maria Fatima Banyumanik Semarang is the same as the form of presentation of the liturgical celebration of the Eucharist in general, in the form of a choir group, and the function of the use of Javanese liturgical songs in the celebration of the eucharist is as a means of communication and as a continuous contribution and cultural stability. Hopefully in the future the church will more intensively inform the celebration of the Javanese eucharist to the people, and hopefully the choir in charge can prepare song texts for the people, so as to increase the readiness and enthusiasm of the people in participating in the celebration of the Javanese eucharist at St. Maria Fatima Banyumanik Semarang.
\end{abstract}

(C) 2020 Universitas Negeri Semarang

\footnotetext{
postcode 50229

Email : 1. 1gnatiuschrist0@gmail.com

2. totoksumarvanto@mail.unnes.ac.id
}

${ }^{凶}$ Departement of Drama, Dance and Music Education, UNNES ISSN 2503-2585 


\section{INTRODUCING}

As the age of the liturgy of the church progressed steadily through the ages, starting from the beginning of its development to the present day in ancient Christianity. The development of church liturgy music coincides with the development of music in the world, the sequence of the history of the world's Catholic liturgy began with the age of the music of the prime church, the music of the early 10th century, the music of the middle ages, the music of the Renaissance, the music of the baroque era, the classical music, the music of the romantic age, and the last was the music of the 20th century. According to Bakok (2013) liturgical music both vocal and instrumental music is music used in the celebration of Catholic liturgies, and according to Adimurti (2005) church liturgical music and church choirs play a huge role in supporting the creation of an atmosphere of worship, especially helping people pray, because with the song of prayer can be expressed in more depth

The church liturgy music has undergone much development as well as innovation in its path to the eucharist, in semarang of The Church Of St. Maria Fatima Banyumanik there is a unique and interesting phenomenon, the eucharist ceremony that used the Javanese language as its introduction to the eucharist ceremony and in the lyrics of the songs performed by the church choir. The study conducted to study the phenomenon of the presentation and function of the javan song that accompanied the ceremony of the Eucharist held on May $26^{\text {th }}$ and June $31^{\text {th }}$, 2019, at The Church Of St. Maria Fatima Banyumanik. The researchers in doing the study contained the rules on liturgy music that applied to the universal catholic church and the terms of the selected liturgy music that the local church has approved, so that the results can then be used as guidance for The Church Of St. Maria Banyumanik Semarang and other churches in the performance of Javanese eucharist ceremony.

Based on the background of the problem, researchers would conclude that the focus of the problem in this study is how the eucharistic singing of the choir was performed in The Catholic Church Of St. Maria Fatima Banyumanik Semarang and what the use of the Javanese song for the choir in the eucharist ceremony of St. Maria Fatima Banyumanik Semarang. The study was conducted to identify, describe and analyse the form of the presentation and function of the Javanese songs used to accompany the ceremony of the Eucharist performed in The Catholic Church Of St. Maria Fatima Banyumanik Semarang on May $26^{\text {th }}$ and June $30^{\text {th }}, 2019$. As for the benefits derived in this study, it is (1). Can find concepts or theories of the presentation and function of the Javanese song in the Catholic church liturgy, (2). To supplement researchers' knowledge of the implementation of the Javanese song for the choir in the eucharist ceremony in the church, (3) as a thought for Semarang University higher education institute especially students from the Drama, Dance, and Music Study Program (music art) to learn more about the liturgy of the church in Javanese (4). To give written information to the public, especially the younger generation as the heir and heir of the nation's culture and thus more familiar with the catholic church liturgy, (5) asa guide to The Church Of St. Maria Fatima Banyumanik and other churches in the Javanese Ceremony of The Eucharist, and (6). The result of this study can use as a reference for the next study.

In this study, researchers also cited some of the results of previous research about the liturgical music of the Catholic church, for example previous research conducted by Yohanes Don Bosko Bakok, (2013), Yuni Suciningsih, (2012), Marzana Poplawska, (2011). Researchers consider the three studies relevant to the research that researchers do

\section{MATERIAL AND METHOD}

The study examined the phenomenon of the use of Javanese songs for church choicists in the ceremony of the eucharist at St. Maria Fatima Banyumanik Semarang, and based on this, the study used a musiological approach to 
qualitative analytic research methods. Qualitative research methods are research methods that are descriptive, do not use numbers, and describe the form of speech, writing, and observation (Paula \& Sumaryanto 2018). While the musicological approach is an approach that uses science in discussing what and how music is academically (Darmayanti et al., 2015). The study is carried out in St. Maria Fatima Banyumanik Semarang on May $29^{\text {th }}$ and June $30^{\text {th }}, 2019$. The focus of the study is the presentation and function of the use of the Javanese song for the choir in the ceremony of the eucharist in the Catholic Church Of St. Maria Fatima Banyumanik Semarang. The objective of the study was that of padre, choir and members of The Catholic Church In St. Maria Banyumanik Semarang who attended the Javanese eucharist ceremony on May $26^{\text {th }}$ and June $30^{\text {th }}$, 2019. Data collection techniques in this study include observation, structured interviews and document studies. The technique of validity used in this study is the extension of participation, triangulation and detailed description. Then from the data that has collected are analyzed with interactive model analyses that include data collection, data reduction, data presentation, and deduction/verification drawing.

\section{RESULT}

\section{Overview of The Research Site}

St. Maria Fatima's Church is located in Kanfer Raya street no. 49, Padangsari, Banyumanik, Semarang city and the position of this church faced northward. St. maria banyumanik, semarang has a $767 \mathrm{~m} 2$ building with the territory border as follows: (1) east bordered antonius 2 elementary school, (2) adjoining trunojoyo viii street and the residential home, (3) north bordered the main kanfer road, (4) south bordered ix/b trunojoyo road.

The church area of St. Maria Fatima Banyumanik Semarang consists of 3 (three) large buildings, church yards, security posts, church bell towers, sculpture of a church, and church parking lots. The first three large buildings were the main buildings of the church used for the ceremony of the eucharist, and then the second was the church meetinghouse and the third was The Darmojuwono Building in which the parish office office, the padres' office, the library, the health clinic, the OMK room, the conference room and the hall.

St. Maria Banyumanik is a church that grows steeped in customs and cultures, whether they are local customs and cultures as well as foreign customs and cultures. Evidence of this is the Javanese ceremony of the eucharist and the bahasa eucharist of the church of St. Maria Fatima Banyumanik, Semarang. The ceremony of the eucharist is carried out according to the schedule made and approved by the church; it is the eucharist schedule in St. Maria Fatima Banyumanik, Semarang:

Table 1. Eucharist cemony schedule in St. Maria Fatima Chruch Banyumanik Semarang

\begin{tabular}{ll}
\hline Day & Time \\
\hline Monday & 05.00 A.M \\
Tuesday & 05.00 A.M \\
Wednesday & 05.00 A.M \\
Thursday & 05.00 A.M \\
Friday & 05.00 A.M \\
Saturday & 05.30 P.M \\
Sunday & 05.30 A.M \\
& 07.30 A.M \\
& 17.00 P.M \\
& 19.00 P.M \\
\hline
\end{tabular}

The Ceremonies of The Indonesian Eucharist (General)

The ceremony of the eucharist was the liturgy ceremony so that in the performance it had an official ordinance designated by the church. Based on the researchers' interviews with Father Aloysius Martoyoto Wiyono, Pr and Fl Father Hartosubono, Pr as the priest in charge of The Church Of St. Maria Fatima Banyumanik, Semarang, he revealed that the eucharist ceremony order and order were the same throughout the world and that its eucharist ordinance was determined from Rome, which 
differentiates only language and is inculturated to the region.

According to Marthasudjita et al. (2011) in the book entitled Masses of Sundays and Holidays and according to Prier (2010: 10-26) in a book entitled The Position of the Song in the Liturgy, the official celebration of the church's eucharistic system is divided into 4 important parts, namely: (1) Opening rites, (2) Liturgy of the Word, (3) Liturgy of the Eucharist, (4) Closing rites. In the opening rites there are, introductions, prayers of repentance, songs of our love for God, songs of glory and opening prayers, and then in the Liturgy there is the first reading, the psalm song, the second reading, the gospel opening song, the gospel reading, the homily / sermon, prayer of confession, and prayer of the people. Further in the Liturgy of the Eucharist there are prayer preparations, preface prayers, sacred songs, supplications, anamnese prayers, Our Father's songs, lambs of God, songs of communion, and prayers of communion, and the last of the Closing Rites are church announcements and thanks to the termination.

\section{The Ceremonies of The Javanese Eucharist at St. Maria Fatima's Church}

On this occasion researchers conducted studies on May 26 $6^{\text {th }}, 2019$ and June $30^{\text {th }}, 2019$ which coincided with the Eucharist ceremony in Javanese in The Church Of St. Maria Fatima Banyumanik, Semarang, based on the interviews that researchers had with padre, The Javanese choir and those attending the eucharist ceremony received data that the eucharist performed in the church of st. maria Fatima banyumanik had the eucharist ceremony in common (using Bahasa) and that distinguished the eucharist ceremony from the eucharist generally only in Javanese. Based on the eucharist book Ing Ngahad Lan Riyaya Taun Liturgy C composed by Father Al Wahjasudibja Pr, and supported by data the author obtained through an interview and personal observation while following the Javanese ceremony of the eucharist in The Church
Of St. Maria Fatima Banyumnik, Semarang may researchers conclude that the order of the Javanese eucharist ceremony is also divided into 4 (four) the essential part such as : Pambuka (opening), (2) Liturgi Sabda (preachment), (3) Liturgi Ekaristi (eucharist), dan (4) Panutup (closing). In the opening there are pitepangan (introductory), pamartobat (prayer of repentance), kidung Gusti nyuwun kawelasan (Lord have mercy on us song), kidung Kamulya (song of glory), sembahyang pambuka (opening prayer), then in the preachment there are waosan I (first reading), kidung panglimbang (song of responses to psalm), waosan II (second reading), kidung cecala (gospel preafce), waosan injil (gospel reading), homily / khotbah, kawula pitados (syahadat prayer), sembahyang umat (prayer of the people), in the eucharist there are kidung pisungsung (tribute prep song), prefasi, kidung suci (holly song), sembahyang puji panuwun Agung (thank prayer), sembahyang anamnese, kidung Rama kawula (Our Father), cempening Allah (the lamb of God), kidung Komuni (comunion song), sembahyang bakda komuni (prayer after comunion), and the last is wara - wara greja (announcement), berkah (closing).

After learning the order of the traditional bahasa eucharist ceremony (indonesian) and the Javanese ceremony of The Church Of St. Maria Fatima Banyumanik Semarang to draw conclusions, finally, a comparative table between Eucharist in common and the Javanese ceremony of The Church Of St. Maria Fatima Banyumanik, Semarang, here is the comparing table:

Table 2. Analysis of Eucharist Ceremonies

\begin{tabular}{ll}
\hline General Eucharist & The Ceremonies of The \\
Ceremonies & Javanese Eucharist \\
\hline RITUS PEMBUKA & PAMBUKA \\
Pengantar & Pitepangan \\
Tobat & Pamartobat \\
Tuhan Kasihanilah & Gusti Nyuwun \\
Kami & Kawelasan \\
Kemuliaan & Kamulyan \\
Doa pembuka & Sembahyang pambuka \\
LITURGI SABDA & LITURGI SABDA \\
Bacaan pertama & Waosan I \\
Mazmur tanggapan & Kidung panglimbang \\
\hline
\end{tabular}




\begin{tabular}{ll}
\hline Bacaan kedua & Waosan II \\
Bait pengantar injil & Kidung cecala \\
Bacaan injil & Waosan Injil \\
Homili & Homili \\
Syahadat & Kawula Pitados \\
Doa Umat & Sembahyang umat \\
LITURGI EKARISTI & LITURGI EKARISTI \\
Doa persiapan & Sembahyang \\
persembahan & pisungsung \\
Prefasi & Prefasi \\
Kudus & Suci \\
Doa syukur agung & Sembahyang puji \\
& panuwun agung \\
Anamnese & Anamnese \\
Bapa kami & Rama kawulo \\
Anak domba Allah & Cempening Allah \\
Komuni & Komuni \\
Doa sesudah komuni & Sembahyang bakda \\
& komuni \\
RITUS PENUTUP & PANUTUP \\
Pengumuman & Wara wara greja \\
Berkat & Berkah \\
\hline
\end{tabular}

After an examination of the aforementioned comparative chart, the writer can finally draw the conclusion that the Javanese Eucharist in The Church Of St. Maria Fatima Banyumanik, either directly or in harmony with the generally bahasa eucharist ceremony in The Church Of St. Maria Fatima Banyumanik Semarang with the Eucharist generally is the Javanese use of the eucharist.

Javanese Song Presentation of The Church Choir In The Eucharist Ceremony At St. Maria Fatima Banyumanik, Semarang

Before discussing the form of a Javanese song in The Church Of St. Maria Fatima Banyumanik, Semarang, researchers would explain the nature of church songs/songs and official and legally established ordinances in The Catholic Church's Eucharist Ceremony. Church Song according Tukan (2013 : xiv) there are 2 types, namely Proprium singing and Ordinarium singing, Proprium singing is a song whose poetry does not change / change according to the theme of the celebration and reading of the Scriptures, the songs include: (1) Opening song, (2) Psalm of response, (3) Gospel / Alleluya introductory verse, (4) Offering song, (5) Communion song, and (6) Closing song while Ordinarium chant is permanent poetry, the example is
(1) Tuhan Kasianilah Kami / Kyrie, (2) Madah Kemuliaan / Gloria, (3) Syahadat / Credo, (4) Kudus / Sanctus, dan (5) Anak domba Allah / Agnus Dei. After doing research and study in the church of st. maria banyumanik, semarang researchers found the data of the song used in Javanese eucharist of the church choir and suitable with the theory of Tukan (2013 : xiv) that in the church of St. Maria Fatima Banyumanik, Semarang, there are also 2 types of songs / songs sung in celebration of the eucharist, namely Proprium and Ordinarium.

Prier (2015 : 24 - 32) in his book entitled Panduan Musik Liturgi, also supported by the theory of Marthasudjita et al (2011: 619 - 625) in his book entitled Masses of Sundays and Holidays, and also supported by Prier theory (2010: 10-26) in his book entitled Position of the Song in the Liturgy, the arrangement of the song and the official position of the song / song in the celebration of the eucharist are as follows:

(1) Opening Song, (2) Tuhan Kasihanilah kami, (3) Madah kemuliaan, (4) Mazmur tanggapan / renungan, (5) Alleluya / ayat pengantar injil, (6) Syahadat / aku percaya, (7) Persiapan persembahan, (8) Kudus, (9) Bapa Kami, (10) Anak domba Allah, (11) Komuni, (12) Madah Pujian, (13) Closing.

After learning the type of church songs/songs and the official eucharistic commemorative ordinances, researchers will next discuss the results of the study of the Javanese version of the eucharist ceremony the writer performed on May 26 and June 30, 2019, at St. Maria Fatima Banyumanik, Semarang. The following is the form of a Javanese song sung by a choir at the time of the Javanese eucharist on May 26 and June 30, 2019 in The Church Of St. Maria Fatima Banyumanik, Semarang:

Table 3. Analysis of Song List In Javanese Eucharist Ceremony on May $26^{\text {th }} 2019$

\begin{tabular}{lll}
\hline No. & Official Song & Song of Javanese Eucharist \\
List & Ceremony on May 26th \\
& 2019 \\
\hline
\end{tabular}




\begin{tabular}{|c|c|c|}
\hline 1 & Lagu Pembuka & $\begin{array}{l}\text { Kidung Adi No. } 350 \text { Pinuji } \\
\text { Sang Kristus } \\
\text { (Lagu Pembuka) }\end{array}$ \\
\hline 2 & $\begin{array}{l}\text { Tuhan } \\
\text { Kasihanilah }\end{array}$ & $\begin{array}{l}\text { Kidung Adi No. } 180 \\
\text { Gusti Nyuwun Kawelasan } \\
\text { (Tuhan Kasihanilah) }\end{array}$ \\
\hline 3 & Kemuliaan & $\begin{array}{l}\text { Kidung Adi No. } 190 \\
\text { Minulya } \\
\text { (Kemuliaan) }\end{array}$ \\
\hline 4 & $\begin{array}{l}\text { Mazmur } \\
\text { Tanggapan }\end{array}$ & Kidung Panglimbang \\
\hline 5 & Alleluya & Kidung cecala \\
\hline 6 & Persembahan & $\begin{array}{l}\text { Kidung Adi No. } 211 \\
\text { Mangga Gusti Kersa } \\
\text { Nampi } \\
\text { (Persembahan ) }\end{array}$ \\
\hline 7 & Kudus & $\begin{array}{l}\text { Kidung Adi No. } 225 \\
\text { Suci } \\
\text { (Kudus) }\end{array}$ \\
\hline 8 & Bapa Kami & $\begin{array}{l}\text { Kidung Adi No. } 139 \\
\text { Rama Kawula Lumrah } \\
\text { (Bapa Kami) }\end{array}$ \\
\hline 9 & $\begin{array}{l}\text { Anak Domba } \\
\text { Allah }\end{array}$ & $\begin{array}{l}\text { Kidung Adi No. } 235 \\
\text { Cempening Allah } \\
\text { (Anak Domba Allah) }\end{array}$ \\
\hline 10 & Lagu Komuni & $\begin{array}{l}\text { Kidung Adi No. } 240 \\
\text { Amba Asih Mring } \\
\text { Pangeran } \\
\text { (Lagu Komuni 1) }\end{array}$ \\
\hline 11 & Lagu Penutup & $\begin{array}{l}\text { Kidung Adi No. } 365 \\
\text { Wus Wungu Risang } \\
\text { Kristus } \\
\text { (Lagu Penutup) }\end{array}$ \\
\hline
\end{tabular}

Table 4. Analysis of Song List In Javanese Eucharist Ceremony on June $30^{\text {th }} 2019$

\begin{tabular}{|c|c|c|}
\hline No. & $\begin{array}{l}\text { Official Song } \\
\text { List }\end{array}$ & $\begin{array}{l}\text { Song of Javanese Eucharist } \\
\text { Ceremony on June } 30 \text { th } \\
2019\end{array}$ \\
\hline 1 & Lagu Pembuka & $\begin{array}{l}\text { Kidung Adi No. } 165 \\
\text { O Bingah Wit Amba } \\
\text { Pareng } \\
\text { (Lagu Pembuka) }\end{array}$ \\
\hline 2 & $\begin{array}{l}\text { Tuhan } \\
\text { Kasihanilah }\end{array}$ & $\begin{array}{l}\text { Kidung Adi No. } 180 \\
\text { Gusti Nyuwun Kawelasan } \\
\text { (Tuhan Kasihanilah) }\end{array}$ \\
\hline 3 & Kemuliaan & $\begin{array}{l}\text { Kidung Adi No. } 190 \\
\text { Minulya } \\
\text { (Kemuliaan) }\end{array}$ \\
\hline 4 & $\begin{array}{l}\text { Mazmur } \\
\text { Tanggapan }\end{array}$ & Kidung Panglimbang \\
\hline 5 & Alleluya & Kidung cecala \\
\hline
\end{tabular}

\begin{tabular}{ccl}
\hline 6 & Persembahan & $\begin{array}{l}\text { Kidung Adi No. 204 } \\
\text { Mangga Samya Sowan } \\
\text { (Persembahan) }\end{array}$ \\
7 & Kudus & $\begin{array}{l}\text { Kidung Adi No. 225 } \\
\text { Suci } \\
\text { (Kudus) }\end{array}$ \\
8 & Bapa Kami & $\begin{array}{l}\text { Kidung Adi No. 139 } \\
\text { Rama Kawula Lumrah } \\
\text { (Bapa Kami) }\end{array}$ \\
9 & $\begin{array}{l}\text { Anak Domba } \\
\text { Allah }\end{array}$ & $\begin{array}{l}\text { Kidung Adi No. 235 } \\
\text { Cempening Allah } \\
\text { (Anak Domba Allah) }\end{array}$ \\
10 & Lagu Komuni & $\begin{array}{l}\text { Kidung Adi No. 246 } \\
\text { Sembah Nuwun } \\
\text { (Lagu Komuni) }\end{array}$ \\
& & Kidung Adi No.416 \\
11 & Lagu Penutup & $\begin{array}{l}\text { Minukya Gusti Allah } \\
\text { (Lagu Penutup) }\end{array}$ \\
\hline
\end{tabular}

From the above analysis table, researchers could conclude that Javanese songs performed in the Javanese eucharist ceremony at St. Maria Fatima Banyumanik, Semarang on $26^{\text {th }}$ May and $30^{\text {th }}$ June, 2019 correspond to the official song of eucharist ceremony. And it can also be seen that the ordinarium song used in the Javaneseeucharist on $26^{\text {th }}$ May and $30^{\text {th }}$ June, 2019, in the church of St. Maria Fatima Semarang used the same ordinarium with Misa Semuwa Theme on Kidung Adi Book. Misa Semuwa Theme has four songs such as: (1) Gusti Nyuwun Kawelasan (Kidung Adi No. 180), (2) Minulya (Kidung Adi No. 190), (3) Suci (Kidung Adi No. 225), dan (4) Cempening Allah (Kidung Adi No. 235). Whereas in Proporium song used in bahasa eucharist ceremony on may $26^{\text {th }}$ and June $30^{\text {th }} 2019$ in The Church Of St. Maria Fatima Banyumanik is different cause according to Tukan (2013 : xiv) Proprium song is a song whose poetry does not change/ change according to the theme of the celebration and reading of the Scriptures, and also based on data that researcher got from an interview with one of the choir officers who served in the celebration of the Javanese language eucharist at St. Maria Fatima Banyumanik, Semarang on May 26, 2019 with Aji Trihatmoko, according to him the song that was delivered at the Eucharist have to be adjusted to the reading was delivered on 
day of Eucharist.. In Javanese eucharist ceremony on May $26^{\text {th }}$ and June $30^{\text {th }} 2019$ in The Church Of St. Maria Fatima Banyumanik, The musical instrument used to accompany the choir was electone organ with diatonic scale and numeric notation used in Javanese songs. The distribution of voice used in Javanese song performed by the choir according to the data of the passages above and according to the interviews the authors performed with the Javanese eucharist at St. Maria Fatima Banyumanik, semarang also diverse, some using only 1 (one) voice or unisono, Some apply the two voices of women and boys or sopranos + alto and tenor + bass and others use the four voices of sopranos, alto, tenor and bass.

After reviewing all the data researchers found while doing research at The St. Maria Banyumanik, Semarang on May 26 ${ }^{\text {th }}$, 2019 and June 30 $0^{\text {th }}, 2019$ researchers were finally able to draw the conclusion that the Javanese eucharist ceremony was performed in The St. Maria Fatima Banyumanik, has the same eucharist ceremony, song list, and song presentation with general eucharist ceremony and the contrast between the eucharist generally and the Javanese eucharist held in The Church Of St. Maria Fatima Banyumanik Semarang only in the language used in the eucharist ceremony that is Javanese which is the result of inculturation between dogma and Javanese culture. The songs performed at the Javanese eucharist ceremony in St, Maria Fatima Banyumanik Semarang almost all use up on the diatonic scale and use numerical notations, and songs - they tend to correspond to the andante and create a reverent atmosphere when accompanying the eucharist ceremony. The Javanese renderings - the song sung in the commemoration of the eucharist were mostly complimentary, ennobly and grateful to the Lord and in accompanying the Javanese ceremony all ordinarium songs were sung by the unisono (one voice) by the officiating choir, while the proprium song was sung by 2 voices (soprano + alto and tenor + bass) and also by 4 voices (soprano, alto, tenor, and bass).

The Fucntion of Javanese Liturgy Song Used for Choir in Eucharist Ceremony in The Chatolic Chruch of St. Maria Fatima Banyumanik Semarang

\section{Communication Function}

Based on information obtained by researchers on May $26^{\text {th }}$ and June $30^{\text {th }}$, 2019, in The Church Of St. Maria Fatima Banyumanik, the Javanese ceremony of the eucharist has been carried out since the beginning of The Church Of St. Maria Fatima banyumanik on 1982 and the Javanese eucharist ceremony in the St. Maria Fatima Banyumanik to this day is still held every Sunday afternoon at the end of the month. According to the interview with Father Fl. Hartosubono, the Pr which on May 26, 2019, presided over the eucharist ceremony in The Church Of St. Maria Fatima Banyumanik Semarang, states that the function and purpose of hosting the Javanese eucharist ceremony is the first to reveal and revive that we are Javanese, and Javanese also have a concept of salvation, And it turned out that the concept of salvation was not in conflict with the concepts of salvation formulated in the Catholic church as well as the Gospel concept of salvation in the struggle for world salvation (Memayu Hayuning Bawana), and then a second for the Javanese and Javanese people who spoke it could express their longing for the Lord. Then according to interviews conducted by researchers with Father Aloysius Martoyoto Wiyono on July $30^{\text {th }}$, 2019, that was held to preside over the Javanese eucharist Ceremony at St. Maria Fatima Banyumanik, the function and purpose of the Javanese eucharit ceremony he said was because most of the members of St. Maria Fatima Banyumanik Semarang is from the Javanese and the ceremony of the eucharist would be far deepening if people could glorify god in their own language or Javanese. Both statement about the function of Javanese eucharist ceremony be in accordance with the theory of 
Hartoyo (2017 : 18) the local language makes the liturgy easier to follow and understand, starting from prayers, reading and singing in the liturgy can be directly absorbed and lived by the local people also accordance with the opinion of Sari \& Setyaprana (2007: 81) the celebration of the Eucharist / Mass of the Javanese language is intended so that the community will further explore the contents and meaning in worship, because according to Dodi (2009: 74) the use of local languages, symbols, and habits of the local people included in the Eucharist will be more touching to the people. Based on the interview data and also supported by several opinions above, the researcher can conclude that the function of the use of Javanese liturgical songs for choirs in the celebration of the eucharist at St. Maria Fatima Banyumanik Semarang is in line with the theory of functions according to Merriam (1964), as a means of communication in the form of communication that is religious and belief.

\section{Continual Contribution and Cultural Stability Fucntion}

Javanese eucharist ceremony in The Chruch of St. Maria Fatima Banyumanik Semarang was the result of inculturation of culture caused according to Marthasudjita (2010 : 40) translating liturgical texts into native languages is of course part of inculturation. It is also in line with Hartoyo (2017: 82) inculturation means the efforts of a religion to adapt to local culture. Based on interviews with the church choir officiated at the eucharist ceremony on May $26^{\text {th }}$ and June $30^{\text {th }}, 2019$, at St. Maria Fatima Banyumanik Semarang, Mr Aji Trihatmoko (44) and Mrs Maria Eka Setyaninglah (39), According to him the purpose of the Java eucharist Ceremony in The Church Of St. Maria Fatima is to nguri-uri (preservation) of the Javanese culture in the St. Maria Fatima Banyumanik Semarang and to preserve the inculturation realized between Java and the church cultures. But according interview Kleopas Biga Patria and Brigita Ayu Komala as the member of the Javanese eucharist in the church of St. Maria Fatima
Banyumanik Semarang, The function and purpose of the Java celebration of the eucharist in The Church Of St. Maria Fatima Banyumanik Semarang is to preserve the Javanese culture not to be forgotten, especially in The St. Maria Fatima Banyumanik Semarang, and to preserve the long-held traditional Javanese eucharisttradition since the founding of St. Maria Fatima Banyumanik. The opinions of the church and community choir officers are relevant to the opinion that inculturation will indirectly save cultural customs that exist in a particular society, so that the culture inherited from ancestors does not just disappear but is increasingly preserved, and inculturation must be maintained as well developed because it helps us understand the celebration of the eucharist and it also while preserving traditional culture (Dodi, 2009 :19).

Based on data obtained by the interviews as well as some of the above theories, researchers could conclude that the function of using Javanese liturgy songs was choirs in eucharist ceremony in The Church Of St. Maria Fatima Banyumanik Semarang in harmony with the theory of Merriam (1964) is as a continuous contribution and cultural stability which means that music contains a teaching serves to continue or continue a teaching to the next generation, so that the teaching or norm continues.

From some of the above opinions, researchers have finally reached the conclusion that the function of using the Javanese liturgy in the ceremony of the Javaneseeucharist in The Church Of St. Maria Fatima Banyumanik Semarang is a means of communication and a continual contribution and cultural stability.

\section{CONCLUSION}

Based on the first discussion of the presentation of the Javanese songs used to accompany theeucharistceremony in the Catholic Church Of St. Maria Fatima Banyumanik Semarang, it is suggested that the Javanese/hymn in The Church Of St. Maria Fatima Banyumanik Semarang contains two kinds of songs/hymns of the proprium and ordinarium corresponding 
to the eucharistceremony. Then for the sequence of the Javanese presentation/ordinance in The Church Of St. Maria Fatima Semarang has been consistent and relevant to the official song of the church and its presentation of the song corresponds generally to the eucharist ceremony in its choir presentation, so that only the use or translation of the eucharist ceremony and liturgy songs used in the Javanese language. Here is the list in Javanese eucharist ceremony in The Chruch of St. Maria Fatima Banyumanik Semarang : (1) Kidung pambuka (lagu pembuka), (2) Gusti nyuwun kawelasan (Tuhan Kasihanilah Kami), (3) Minulya (kemuliaan), (4) Kidung panglimbang (mazmur tanggapan), (5) Kidung Cecala (Alleluya), (6) Kidung Pisungsung (lagu persembahan), (7) Suci (kudus), (8) Rama Kawula Lumrah (Bapa Kami), (9) Cempening Allah (Anak domba Allah), (10) Kidung komuni (lagu komuni), (11) Kidung Panutup (lagu penutup).

Associated with function, authors can draw final conclusions about the function of the Javanese song in the ceremony of the Javanese eucharist in The Church Of St. Maria Fatima Banyumanik Semarang as a means of communication and as a contribution to sustainable and cultural stability.

\section{Proposition}

Based on the study that researchers obtained, researchers finally obtained some suggestions for those related in the context of the presentation of forms and the function of the liturgy of the language song for the choir in the ceremony of the eucharist in The Church Of St. Maria Fatima Banyumanik Semarang.

\section{For Chruch administrator and Stewards}

Based on studies conducted by researchers, the enthusiastic Javanese eucharist in The Church Of St. Maria Banyumanik Semarang is less because of the people's inability to participate in the Javanese eucharist ceremony, due to the lack of announcement and the call from the church officials to the masses to prepare and carry out the Javanese eucharist manual, Researchers hope that for future church leaders and other church authorities to increase in notification and appeals to the people about the Javanese eucharist ceremony so that the people can prepare before attending the Javanes ucharist Ceremony in The Church Of St. Maria Fatima Banyumanik.

\section{For Choir Members}

Based on research conducted by researchers, the lack of enthusiasm for the singing of the eucharist was due to the fact that the people did not have the singing text and had forgotten to bring the Javanese celebration manual, researchers hoped that in the future the local chorus would be able to prepare a simple song text to share with the needy, So that people can be more enthusiastic about singing together in the Javanese eucharist ceremony at St. Maria Fatima Banyumanik Semarang.

\section{For Member of The Chruch of St. Maria Fatima Banyumanik Semarang}

Based on research conducted by researchers regarding the function of Javanese in eucharist ceremony, researchers can conclude that the use of Javanese in eucharist ceremony is an innovation that we must preserve, since it used Javanese in eucharist and indirect way to and preserve the Javanese culture, Therefore the author hopes that people in St. Maria Fatima Banyumanik can increase his interest in observing the eucharist festivities in Javanese, so that the inculturation that has happened in St. Maria Fatima Banyumanik will always be awake and can eventually be a good example for other catholic churches.

\section{For Reseachers}

In addition to some of the above suggestions, researchers also hope that the study will be useful to the researchers and to the readers and that it will provide reference to further research.

The writer expresses thanks to:

1. Prof. Dr. Fathur Rokhman, M. Hum. The Rector Of Semarang 
State University who has given a writer the opportunity to get a formal education at Semarang State University.

2. Dr. Sri Rejeki Urip, M. Hum. , The Dean Of The Language And Arts Faculty Of Semarang State University who has given permission to the writer, so that the study at St. Maria Fatima Banyumanik Semarang is possible.

3. Dr. Udi Utomo M. Si. , Chairman Of The Dance And Music Arts Study Program, Language And Arts Department, Semarang State University that has given guidance and direction during the study of the writer at the Semarang State University.

4. All of the priests and staff employees of The Church Of St. Maria Banyumanik who have given us research permits and have agreed to provide information that is useful in scriptuzation.

5. Associates who assist in journal drafting.

\section{REFERENCES}

Adimurti, J. T. (2005). Inkulturasi Musik Gereja di Batak Toba dan Simalungun. HARMONIA: JURNAL PENGETAHUAN DAN PEMIKIRAN SENI, 6(3).

Bakok, Y. D. B. (2013). Musik Liturgi Inkulturatif di Gereja Ganjuran Yogyakarta. RESITAL : JURNAL SENI PERTUNJUKAN, 14(1), 24-31.

Darmayanti, D., Ghazali, I., \& Syahrani, A. (2015). Tinjauan Musikologi Lagu Sekapor Sireh Dalam Tradisi Penyambutan Di Keraton Amantubillah. Jurnal Pendidikan Dan Pembelajaran Khatulistiwa, 4(12), 3.

Dodi, D. (2009). Inkulturasi Sebagai Jalan Bagi Umat Paroki Kristus Raja Cigugur
Dalam Memahami Makna Perayaan Ekaristi. Universitas Sanata Darma.

Hartoyo, A. R. W. (2017). Penggunaan Bahasa Jawa Dalam Perayaan Ekaristi di Stasi Santo Fransiskus Xaverius Kemranggen, Paroki Santo Yohanes Rasul Kutoarjo. Universitas Sanata Darma.

Marthasudjita, E. (2010). Proses Inkulturasi Liturgi di Indonesia. Studia Philosophica et Theologica, 10(1), 40.

Marthasudjita, E., S, K. J., Sukawalyana, I., Supriya, P., Witokaryana, Y. S., Suwondo, A. Y., ... Widodo, A. A. (2011). Misa Hari Minggu dan Hari Raya. (Sinubyo, Naning, \& Erdian, Eds.). 2011: Kanisius.

Merriam, A. P. (1964). The Antrophology of Music. Illinois: Northwetern University Press.

Paula, B. M., \& F., T. S. (2018). Teknik Vokal dan Peran Pemandu Nyanyian Jemaat di Gereja Kristen Jawa Ngesrep Kota Semarang. Journal Unnes, 7(1), 14-24.

Poplawska, M. (2011). Christianity and Inculturated Music in Indonesia. Southeast Review of Asian Studies, 33, 186-198.

Prier, K.-E. (2010). Kedudukan Nyanyian Dalam Liturgi. Yogyakarta: Pusat Musik Liturgi.

Prier, K.-E. (2015). Panduan Musik Liturgi. Yogyakarta: Pusat Musik Liturgi.

Sari, S. M., \& Setyaprana, J. (2007). Inkulturasi Budaya Jawa Dalam Interior Gereja Katolik Redemptor Mundi di Surabaya. Demensi Interior, $5(2), 81$.

Suciningsih, Y. (2012). Inkulturasi Musik Gamelan Jawa Pada Musik Liturgi Dalam Ekaristi Di Gereja Hati Kudus Tuhan Yesus Pugeran Yogyakarta. Universitas Negeri Yogyakarta.

Tukan, Y. G. (2013). Peran dan Fungsi Nyanyian Proporium dan Ordinarium Masa Biasa dalam Tata Perayaan Ekaristi Gereja Khatolik di Paroki Santo Yohanes Rasul Pringwulung Yogyakarta. Universitas Negeri Yogyakarta. 